\title{
STUDIES ON BIOLOGICALLY IMPORTANT COPPER(II) / MANGANESE(II) / URANYL(II) - NORVALINE BINARY COMPLEXES
}

\author{
Brij Bhushan Tewari \\ Department of Chemistry, Faculty of Natural Sciences, University of Guyana, \\ P. O. Box: 101110, Georgetown, Guyana \\ brijtew@yahoo.com
}

\begin{abstract}
In coordination compounds studies, a knowledge of the magnitude of the stability constants of complexes is necessary for preliminary quantitative treatment. Described herein is a method that involves the use of advanced ionophoretic technique for the study of the equilibria in binary complex systems in solution. This method is based upon the migration of a spot of the metal ion on a paper strip at different $\mathrm{pH}$ values of background electrolyte containing $0.1 \mathrm{M}$ perchloric acid and $0.01 \mathrm{M}$ norvaline. A graph of $\mathrm{pH}$ against mobility provides information about the nature of the complexation and helps in calculating stability constants. Using this method, the stability constants of binary complexes metal(II) - norvaline have been determined to be $(8.11 \pm 0.02,7.03 \pm 0.09) ;(3.77 \pm 0.11,2.39 \pm$ $0.07)$ and $(7.59 \pm 0.05,6.17 \pm 0.04)$ (log $\mathrm{K}$ values) for $\mathrm{Cu}(\mathrm{II}), \mathrm{Mn}(\mathrm{II})$ and $\mathrm{UO}_{2}(\mathrm{II})$ complexes, respectively, at $35^{\circ} \mathrm{C}$.
\end{abstract}

Key words: electrophoretic technique; complexation reactions; copper(II) complexes; manganese(II) complexes; uranyl(II) complexes; norvaline; stability constants

\section{ИСПИТУВАЊА НА БИОЛОШКИ ВАЖНИ БИНАРНИ КОМПЛЕКСИ НА БАЗА НА БАКАР(ІІ)/МАНГАН(ІІ)/УРНИЛ(II) - НОРВАЛИН}

\begin{abstract}
Во испитувањата на координативните соединенија, пред да се започне со нивното квантитативно испитување, потребно е да се има познавање за големината на константата на стабилност на комплексите. Овде е опишан метод кој вклучува употреба на напредна техника на јонофореза за испитување на рамнотежата на бинарни комплексни ситеми во раствор. Овој метод се базира на миграцијата на петното на метален јон на хартиена лента при различни вредности на $\mathrm{pH}$ на носечкиот електролит кој содржи $0,1 \mathrm{M}$ перхлорна киселина и $0,01 \mathrm{M}$ норвалин. Графикот на зависноста на $\mathrm{pH}$ од мобилноста дава информација за природата на комплексирањето и помага во пресметување на константите на стабилноста. Пресметано е дека константите на стабилност на бинарните комплекси метал(II) - норвалин изнесуваат $(8,11 \pm 0,02,7,03 \pm 0,09),(3,77 \pm 0,11$, $2,39 \pm 0,07)$ и $(7,59 \pm 0,05,6,17 \pm 0,04)\left(\log K\right.$ вредности) за комплексите на $\mathrm{Cu}(\mathrm{II}), \mathrm{Mn}(\mathrm{II})$ и $\mathrm{UO}_{2}(\mathrm{II})$, соодветно, на $35^{\circ} \mathrm{C}$.
\end{abstract}

Клучни зборови: техника на електрофореза; реакции на комплексирање; комплекси на бакар(II); комплекси на манган(II); комплекси на уранил(II); норвалин; константи на стабилност

\section{INTRODUCTION}

Data on the complexation of essential metal ions and the bioactive ligands norvaline gives an important insight into many physiochemical processes. Norvaline is an amino acid $\left(\mathrm{C}_{5} \mathrm{H}_{11} \mathrm{NO}_{2}\right)$ isomeric with valine, and is commonly made synthetically. It has several significances in biological systems (1-9). The importance of metal ions to vital functions in living systems and for the well being of living organisms is now well established. Copper and manganese are classified as essential metals, while uranyl is a toxic metal. Average copper and manganese content of a healthy human (body weight, $70 \mathrm{~kg}$ ) are 0.100 and $0.012 \mathrm{~g} /$ individual, respectively. The normal recommended amount of uranium in human diet is $0.001-0.002 \mathrm{mg} /$ day (10). Copper(II), manganese(II) and uranly(II have significant biomedical applications, but are toxic at higher concentration (11-27). 
The shortcomings of paper ionophoretic technique like variation in the temperature during electrophoresis, capillary flow on paper, electroosmosis, and adsorption effects on the mobility of charged moieties, are well known (28). In this work we describe a technique that overcomes these limitations. The technique is very convenient, simple in use, and yields results in fair agreement with the accepted literature values.

Recent publications from our laboratory (2931) described a new method for the study of binary complexes by using paper ionophoretic technique. The present work is an extension of the technique, and reports an observation on the determination of the stability constant values of binary complexes of copper(II)/manganese(II)/uranyl(II) - norvaline.

\section{EXPERIMENTAL SECTION}

\subsection{Apparatus}

A Systronic (Naroda, India), Model 604, electrophoresis systems was used. The apparatus consisted of a PVC moulded double tanks vessel. A significant change in the instrument were made: two hollow rectangular plates covered with thin polythene sheets were used through which thermostated water was run for controlling the temperature, and the tanks were closed with a transparent PVC moulded lid. The whole assembly was tight, which prevented moisture changes, which may upset the equilibria in a paper strips. The assembly design thus kept to a minimum the disturbing effect of evaporation from the unwanted liquid flow in the paper. Each electrolyte tank contained a separate electrode chamber in which the anode and cathode were placed, respectively.

Whatman No. 1 filter papers for chromatography were used for the purpose of electrophoresis. Elico (Hyderdad, India) Model $\mathrm{L}_{1-10} \mathrm{pH}$ meter (glass and calomel electrode assembly, working on $220 \mathrm{~V} / 50 \mathrm{~Hz}$ established a.c. mains) was used for $\mathrm{pH}$ measurements. The $\mathrm{pH}$ meter was calibrated with buffer solution of $\mathrm{pH}$ 7.0.

\subsection{Chemicals}

Solutions of copper(II), manganese(II) and uranyl(II) metal perchlorate were prepared by preliminary precipitation of metal carbonates from $0.1 \mathrm{~mol} \mathrm{~L}^{-1}$ solution of sodium carbonate (AnalaR grade; $\mathrm{BDH}$, Poole, UK). The precipitate was thoroughly washed with boiling water and treated with predetermined amounts of $1 \%$ perchloric acid. The resulting mixture was heated to boiling on a water bath and was then filtered. The metal contents of the filtrates were determined and the final concentration was kept at $5.0 \cdot 10^{-3} \mathrm{~mol}^{-1}$.

Metal spots were detected on the paper using a $0.1 \%$ solution of 1 - (2-pyridylazo) - 2 - naphthol (PAN) (E. Merck, Darmstadt, Germany). A saturated aqueous solution $(0.9 \mathrm{ml})$ of silver nitrate was diluted with acetone to $20 \mathrm{ml}$. Glucose, as the black spot, was detected by spraying with this solution and then with $2 \%$ ethanolic solution of sodium hydroxide.

\subsection{Background electrolyte}

The background electrolyte used in the study of binary complexes were $0.1 \mathrm{~mol}^{-1}$ perchloric acid and $0.01 \mathrm{~mol} \mathrm{l}^{-1}$ norvaline. Stock solution of $5.0 \mathrm{~mol} \mathrm{l}^{-1}$ perchloric acid was prepared from $70 \%$ solution (SDS, AnalaR grade). $2.0 \mathrm{~mol} \mathrm{1}^{-1}$ sodium hydroxide (AnalaR grade) and $0.5 \mathrm{~mol}^{-1}$ norvaline $(\mathrm{BDH}$, Poole, $\mathrm{UK})$ solutions were prepared. Each solution was standardized using appropriate methods.

\subsection{Procedure}

The hollow base plate in the instrument was verified to be horizontal with spirit level. A 150 $\mathrm{mL}$ volume of background electrolyte was placed in each tank of the electrophoretic apparatus. The levels of the two tank solutions were equalized by a siphon. These precaution were taken to stop any gravitational and hydrodynamic flow. Paper strips (Whatman No. 1) of $30 \times 1 \mathrm{~cm}^{2}$ size were soaked in background electrolyte and the excess electrolyte solution was blotted by pressing them gently within the folds of dry filter paper sheets. Paper strips in duplicate were spotted with metal ions and glucose in the centre with a micropipette and were subsequently placed on the base plate and sandwiched under the upper hollow metallic plate with the ends of the strips immersed in the tank solutions on both sides. A potential difference of $220 \mathrm{~V}$ was applied between the tank solutions, and electrophoresis was carried out for 60 minutes. Afterward the strips were removed with the help of glass rod, dried, and the spots were developed. The distance recorded in duplicate strips differed $\pm 5 \%$ and the average was calculated. The distances 
travelled towards anode were given a negative sign and those towards the cathode positive. The actual distance of the sample spot moved was corrected for the distance travelled by the reference glucose spot. The mobilities were calculated by dividing the movement with the potential gradient and expressed in $\mathrm{cm}^{2} \mathrm{~V}^{-1} \mathrm{~min}^{-1}$.

\section{RESULTS}

The ionophoretic mobility of metal spot against $\mathrm{pH}$ yields a curve with a number of plateaus, as shown in Figure 1. Every plateau indicates the formation of a certain complex species. A plateau is an indication of a $\mathrm{pH}$ range where speed is practically constant. The first one in the beginning corresponds to a region in which metal ions are uncomplexed. In this region of low $\mathrm{pH}$, the concentration of $\left[\begin{array}{lllll}\mathrm{CH}_{3} & \mathrm{CH}_{2} & \mathrm{CH}_{2} & \mathrm{CH} & \left(\mathrm{NH}_{3}{ }^{+}\right)\end{array}\right.$ $\mathrm{COOH}]$ species of norvaline is maximum and this species is non-complexing. Beyond this range, metal ion spots have progressively decreasing mobility, and complexation of metal ions should be taking place with anionic species of norvaline whose concentration increases progressively with the increase of $\mathrm{pH}$. Figure 1 shows three plateaus for copper(II), manganese(II) and uranyl(II) metal ions. All three metal ions form two complexes with norvaline anion. The literature also assigns prominent liganding property to the zwitterion species [32]. It is therefore assumed that the anionic species of norvaline $\left[\mathrm{CH}_{3} \mathrm{CH}_{2} \mathrm{CH}_{2} \mathrm{CH}\left(\mathrm{NH}_{2}\right)\right.$ $\left.\mathrm{COO}^{-}\right]$has complexed with the metal ions to form different complex species.

Figure 1 reveals that $\mathrm{Cu}^{2+}, \mathrm{Mn}^{2+}$ and $\mathrm{UO}_{2}{ }^{2+}$ metal ions form their first complex movement towards negative electrode. Hence one $\left[\mathrm{CH}_{3} \mathrm{CH}_{2}\right.$ $\left.\mathrm{CH}_{2} \mathrm{CH}\left(\mathrm{NH}_{2}\right) \mathrm{COO}^{-}\right]$must have combined with $\mathrm{Cu}^{2+}, \mathrm{Mn}^{2+}$ and $\mathrm{UO}_{2}{ }^{2+}$ metal ions to give $\left[\mathrm{Cu}\left\{\mathrm{CH}_{3}\right.\right.$ $\left.\left.\mathrm{CH}_{2} \mathrm{CH}_{2} \mathrm{CH}\left(\mathrm{NH}_{2}\right) \mathrm{COO}\right\}\right]^{+}$, [Mn $\left\{\mathrm{CH}_{3} \mathrm{CH}_{2} \mathrm{CH}_{2}\right.$ $\left.\left.\mathrm{CH}\left(\mathrm{NH}_{2}\right) \mathrm{COO}\right\}\right]^{+}$and $\left[\mathrm{UO}_{2}\left\{\mathrm{CH}_{3} \mathrm{CH}_{2} \mathrm{CH}_{2} \mathrm{CH}\right.\right.$ $\left.\begin{array}{lll} & \mathrm{NH}_{2} & \mathrm{COO}\end{array}\right]^{+}$complex cations, respectively. With further increase of $\mathrm{pH}$, the mobility of all three metal ions decreased, giving rise to a third plateau with zero mobility, indicateing its neutral nature. The third plateau in each case is due to a 1:2 metal - ligand complex. Hence, two $\left[\mathrm{CH}_{3} \mathrm{CH}_{2}\right.$ $\left.\mathrm{CH}_{2} \mathrm{CH}\left(\mathrm{NH}_{2}\right) \mathrm{COO}^{-}\right]$must have combined with $\mathrm{Cu}^{2+}, \mathrm{Mn}^{2+}$ and $\mathrm{UO}_{2}{ }^{2+}$ to give $\left[\mathrm{Cu}\left\{\mathrm{CH}_{3} \mathrm{CH}_{2} \mathrm{CH}_{2}\right.\right.$ $\left.\mathrm{CH}\left(\mathrm{NH}_{2}\right) \mathrm{COO}_{2}\right]$, [Mn $\left\{\mathrm{CH}_{3} \mathrm{CH}_{2} \mathrm{CH}_{2} \mathrm{CH}\left(\mathrm{NH}_{2}\right)\right.$
$\left.\mathrm{COO}\}_{2}\right]$ and $\left[\begin{array}{llllll}\mathrm{UO}_{2} & \left\{\mathrm{CH}_{3}\right. & \mathrm{CH}_{2} & \mathrm{CH}_{2} & \mathrm{CH} & \left(\mathrm{NH}_{2}\right)\end{array}\right.$ $\mathrm{COO}_{2}$ ] metal complexes. In view of the above observation, the complexation of metal ions with the norvaline anion may be given as:

$$
\begin{aligned}
& M^{2+}+L^{-} \stackrel{K_{1}}{\longleftrightarrow} M L^{+}, \\
& M L^{+}+L^{-} \stackrel{K_{2}}{\longleftrightarrow} M L_{2},
\end{aligned}
$$

wherein $\mathrm{M}^{2+}$ represents the $\mathrm{Cu}^{2+}, \mathrm{Mn}^{2+}$ and $\mathrm{UO}_{2}{ }^{2+}$ metal cations, $\left[\mathrm{L}^{-}\right]$is the norvaline anion; and $K_{1}$ and $K_{2}$ are the first and second stability constants, respectively.

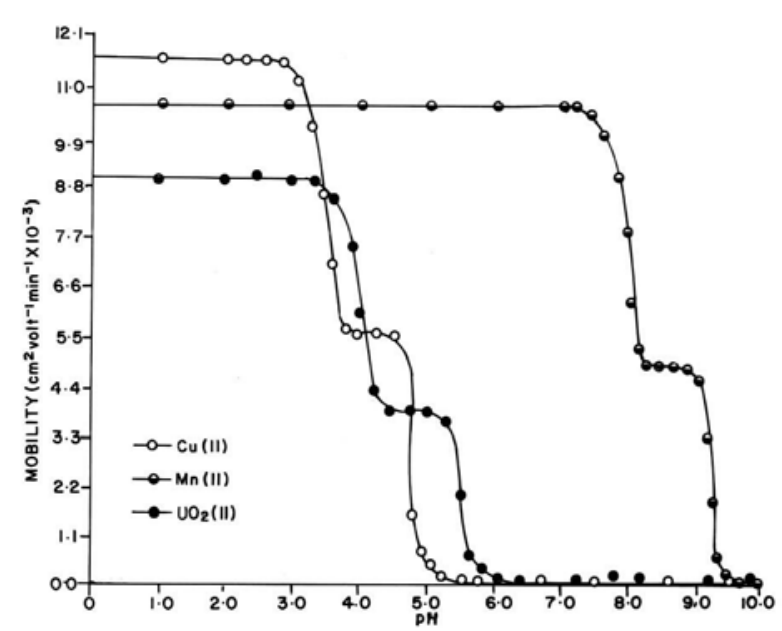

Fig. 1. Mobility curve for the metal(II)-norvaline systems. $\rightarrow-0 \mathrm{Cu}(\mathrm{II})$-norvaline, $-\boldsymbol{0}=\mathrm{Mn}(\mathrm{II})$-norvaline, $\rightarrow-=\mathrm{UO}_{2}(\mathrm{II})-$ norvaline. Concentration of $\mathrm{Cu}(\mathrm{II}), \mathrm{Mn}(\mathrm{II})$ and $\mathrm{UO}_{2}(\mathrm{II})=0.005 \mathrm{~mol} \mathrm{l}^{-1}$. The paper strips were spotted with $0.1 \mu$ of sample solutions and glucose (for making osmotic corrections)

The metal spot on the paper is thus a combination of the uncomplexed metal ions; 1:1 complex, and 1:2 complex. The spot is moving under the influence of the electric field, and the overall mobility is given by the equation of Jokl [33]:

$$
U=\frac{\sum u_{x p} \cdot \beta_{x p}[H p L]^{X}}{\sum \beta_{x p}[H p L]^{X}},
$$

wherein $[H p L]^{\mathrm{x}}$ is the concentration of general complex species; $\beta_{x \cdot p}$ is the overall mobility constant of the complex; $U_{x \cdot p}$ is the speed of the general complex $\left[M(H p L)^{\mathrm{x}}\right]$ present in the combination. On taking into consideration different equilibria, the above equation is transformed into the following form: 


$$
U=\frac{u_{0}+u_{1} K_{1}\left[L^{-}\right]+u_{2} K_{1} K_{2}\left[L^{-}\right]^{2}}{1+K_{1}\left[L^{-}\right]+K_{1} K_{2}\left[L^{-}\right]^{2}}
$$

wherein $u_{0}, u_{1}$, and $u_{2}$ are the mobilities of the uncomplexed metal ions, $1: 1$ and 1:2 metal complexes, respectively. Eq. (4) was used for the determination of the stability constants of the metal ions with norvaline. For calculating the first stability constant, $K_{1}$, the region between first and second plateau is pertinent. The overall mobility $U$ is equal to the arithmetic mean of the mobility of the uncomplexed metal ion, $u_{0}$, and that of the first complex, $u_{1}$, at a $\mathrm{pH}$, where

$$
K_{1}=1 /\left[\mathrm{CH}_{3} \mathrm{CH}_{2} \mathrm{CH}_{2} \mathrm{CH}\left(\mathrm{NH}_{2}\right) \mathrm{COO}^{-}\right] \text {. }
$$

With the help of dissociation constants of norvaline $\left[k_{1}=10^{2.31}, k_{2}=10^{9.65}\right.$ (electrophoretically obtained values)], the concentration of the norvaline anion $\left[L^{-}\right]$is determined for the $\mathrm{pH}$ using the following equation, from which $K_{1}$, can be calculated.

$$
\left[L^{-}\right]=\frac{\left[L_{T}\right]}{1+[H] / k_{2}+[H]^{2} / k_{1} \cdot k_{2}},
$$

wherein $\left[L_{T}\right]$ is the total concentration of norvaline $\left(0.01 \mathrm{~mol} \mathrm{~L}^{-1}\right)$; and $k_{1}$ and $k_{2}$ are the first and second dissociation constants of pure norvaline, respectively. The dissociation of norvaline can be represented as:

$$
\begin{gathered}
{\left[\mathrm{CH}_{3} \mathrm{CH}_{2} \mathrm{CH}_{2} \mathrm{CH}\left(\mathrm{NH}_{3}{ }^{+}\right) \mathrm{COOH}\right]} \\
-\mathrm{H}^{+} \downarrow \uparrow k_{1} \\
{\left[\mathrm{CH}_{3} \mathrm{CH}_{2} \mathrm{CH}_{2} \mathrm{CH}\left(\mathrm{NH}_{3}^{+}\right) \mathrm{COO}^{-}\right]} \\
-\mathrm{H}^{+} \downarrow \uparrow k_{2} \\
{\left[\mathrm{CH}_{3} \mathrm{CH}_{2} \mathrm{CH}_{2} \mathrm{CH}\left(\mathrm{NH}_{2}\right) \mathrm{COO}^{-}\right]}
\end{gathered}
$$

The stability constant of second complex, $\mathrm{K}_{2}$, can be calculated by taking into consideration the region between the second and third plateau of the mobility curve. These calculated values are given in the Table 1.

\section{CONCLUSION}

Table 1 shows that in each case the value of the first stability constant $K_{1}$, is higher than that of the second stability constant $K_{2}$. It is therefore inferred that the coordinating tendency of the ligand decreases with the higher state of aggregation. Ta- ble 1 also shows that stability constants follow the order:

$$
\text { copper(II) }>\text { uranyl(II) > manganese(II). }
$$

According to standard deviation (statistics), the precision of the method is limited to that of paper electrophoresis, and uncertainty in the result is $\pm 5 \%$. Hence, it can not immediately replace the most reliable methods, even thought it is new approach deserving further development.

\section{Table 1}

Stability constants of binary complexes of copper(II), manganese(II) and uranyl(II) with norvaline

\begin{tabular}{ccccc}
\hline \hline $\begin{array}{c}\text { Metal } \\
\text { ions }\end{array}$ & $\begin{array}{c}\text { Stability } \\
\text { constants }\end{array}$ & Complexes & \multicolumn{2}{c}{$p K_{1}$ and $p K_{2}$} \\
\hline $\mathrm{Cu}^{++}$ & $K_{1}$ & $\mathrm{ML}^{+}$ & $8.11 \pm 0.02$ & $8.17(34)$ \\
& $\mathrm{K}_{2}$ & $\mathrm{ML}_{2}$ & $7.03 \pm 0.09$ & $6.87(34)$ \\
\hline $\mathrm{Mn}^{++}$ & $K_{1}$ & $\mathrm{ML}^{+}$ & $3.77 \pm 0.11$ & $3.30(35)$ \\
& $\mathrm{K}_{2}$ & $\mathrm{ML}_{2}$ & $2.39 \pm 0.07$ & $1.89(35)$ \\
\hline $\mathrm{UO}_{2}{ }^{++}$ & $K_{1}$ & $\mathrm{ML}^{+}$ & $7.59 \pm 0.05$ & - \\
\hline \hline
\end{tabular}

Ionic strength $=0.1 \mathrm{~mol} \mathrm{l}^{-1}$; temperature $=35^{\circ} \mathrm{C}$; norvaline anion: $\left[\mathrm{CH}_{3} \mathrm{CH}_{2} \mathrm{CH}_{2} \mathrm{CH}\left(\mathrm{NH}_{2}\right) \mathrm{COO}^{-}\right] ; \mathrm{M}=$ metal cations $\left(\mathrm{Cu}^{2+}, \mathrm{Mn}^{2+}\right.$ and

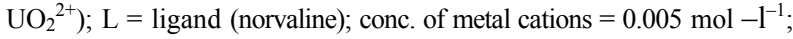
$\mathrm{pH}$ of the solution was maintained by addition of sodium hydroxide. The paper strips were spotted with $0.1 \mu 1$ of sample solution and glucose (for making osmotic correction).

It is clear from the Table 1 that the calculated stability constants are similar to those reported in the literature. The slight deviation in the values obtained from different sources is mainly due to the differences in temperature and ionic strength used by different workers. The stability constants of metal complexes can be very easily calculated by this technique, therefore the present method is advantageous over other methods (viz, polarographic, potentiometric, solubility etc.). It can also be concluded that norvaline may be used to reduce the level of copper(II), manganese(II) and uranyl(II) in biological systems. This simple electrophoretic technique has thus proved to be helpful in deciding whether a mixed complex system is formed, and if it is formed its stability constants can readily be calculated. 


\section{REFERENCES}

[1] K. Elnekave, R. Siman-Tov, S. Ankri, Consumption of Larginine mediated by entamoeba histolytica L-arginase inhibits amoebicidal activity and nitric oxide production by activated macrophages, Parasite Immunol. 25 (11-12), 597-608 (2003).

[2] C. S. Coleman, G. Hu, A. E. Pegg, Putrescine biosynthesis in mammalian tissues, Biochem. J. 379, 849-855 (2004).

[3] C. Chang, J. C. Liao, L. Kuo, Macrophase arginase promotes tumor cell growth and suppresses nitric oxide mediated tumor cytotoxicity, Can. Res. 61, $1100-1106$ (2001).

[4] A. Djeraba, E. Musset, N. Rooijen, P. Quere, Resistance and susceptibility to Marek's disease, nitric oxide synthase / arginase activity balance, Veterinary Microbiol. 86 (3), 229-244 (2002).

[5] J. Lee, J. W. Finley, J. M. Harmly, Effect of selenium fertilizer on free amino acid composition of Broccoli determined by gas chromatography with flame ionization and mass selective detection, J. Agri. Food Chem. 53, 9105-9111 (2005)

[6] M. T. Talaue, V. Venketaraman, N. D. Connell, Arginine homeostatis in J774.1, Macrophages in the context of mycobacterium bovis BCG infection, J. Bacteriol. 188 (13), 4830 - 4840 (2006).

[7] K. Tipton, Nonessential amino acids are not necessary to stimulate net muscle protein synthesis in healthy volunteers, J. Nutr. Biochem. 10(2), 89-95 (2003).

[8] V. Kaartinen, J. C. Williams, J. Tomich, J. R. Yates, L. E. Hood, I. Mononen, Glycosapararginase from leukocytes. Inactivation and covalent modification with diazo oxonorvaline, J. Biol. Chem. 266 (9), 5860-5869 (1991).

[9] C. Chang, B. Zoghi, J. C. Liao, L. Kuo, The involvement of tyrosine kinases, cyclic AMP/protein Kinase A, and p38 nitrogen-activated protein kinase in IL-13- mediated Arginase I induction in macrophages, J. Immunol. 165, 2134-2141 (2000).

[10] D. Banerjea, Some aspects on the role of metal ions in biological systems, Everyman's Sci. 29 (6), 176-184 (1995).

[11] B. Kozlevear, N. Lah, I. Leban, F. Pohleven, P. Segedin, Synthesis and characterization of fatty acid copper(II) carboxylates with N, N-diethylnicotinamide, Croatica Chemica Acta, 73 (3), 733-741 (2000).

[12] S. M. Romanowski, F. Tormena, V. A. Santos, M. F. Hermann, A. S. Mangrich, Solution studies of copper(II) complexes as a contribution to the study of the active site of galactose oxidase, J. Braz. Chem. Soc. 15(6), 1-6 (2004).

[13] E. K. Efthimiadon, H. Thomdaki, Y. Sanakis, C. P. Raptopoulou, N. Katsaros, G. Psomas, Structure and biological properties of the copper(II) complex with the quinolone antibacterial drug N-propyl-norfloxacin and 2.2'bipysidine, J. Inorg. Biochem. 101 (1), 64-73 (2007).

[14] L. Larabi, Y. Harek, A. Reguig, M. M. Mostafa, Synthesis, structural study and electrochemical properties of copper(II) complexes derived from benzene and $\mathrm{p}$ - toluenesulphonyl-hydrazones, J. Serb. Chem. Soc. 68 (2), 85-95 (2003).

[15] N. Guskos, J. Types, G. J. Papadopoulos, M. Maryniak, $\mathrm{K}$. Aidinis, The linewidths and pintegrated intensities of the d-d transitions in photoacoustic spectra of polyamine copper(II) complexes, Materials Sci. - Poland 23(4), 1-6 (2005).

[16] C. Medina, M. J. Santos-Martinez, A. Radomski, O. I. Corringan, M. W. Radomski, Nanoparticles: Pharmacological and toxicological significance, Br. J. Pharmacol. 150, 552-558 (2007).

[17] M. Aschner, Manganese: Brain transport and emerging research needs, Environ. Health Prospect, 108 (3), 429432 (2000).

[18] Q. -Y. Zhu, J. Dai, D. -X. Jia, L. -H. Cao, H. -H. Lin, Manganese(II) complexes coordinated by a new derivatives of bi pyridine, Eur. J. Inorg. Chem. 24, $4789-4794$ (2004).

[19] S. B. Liu, L. Perera, L. G. Pedersen, Binuclear manganese(II) complexes in biological systems, Molecular Phys. 105 (19-22), 2893-2898 (2007).

[20] S. H. Reaney, G. L. O. Kwik - Uribe, D. R. Smith, Manganese oxidation state and its implications for toxicity, Chem. Res. Toxicol. 15 (9), 1119-1126 (2002).

[21] S. Chitra, R. Sommalar, C. S. S. Devi, Effect of fish oil on cigarette smoking induced dyslipidemia in rats, Indian J. Pharmacol. 32, 114-119 (2000).

[22] M. Sulkowska, E. Skrzydlewska, I. Daniszewska, Effect of cyclophosphamide - induced generation reactivate oxygen forms on ultrastructure of the liver and lung, Bull. Vet. Inst. Pulway, 46, 239-246 (2002).

[23] H. Wickert, K. Zoar, A. Grauer, M. John, M. Zimmermann, F. Gillardon, Differential induction of protooncogene expression and cell death in ocular tissues following ultraviolet irradiation of the rat eye, $\mathrm{Br}$. J. Ophthalmol. 83, 225-230 (1999).

[24] J. L. Anderson, H. B. Spitz, J. H. Yiin, Characterization of internal exposure to enriched uranium at a former gaseous diffusion plant, Health Phys. 93 (6), 636-644 (2007).

[25] W. E. Briner, The evolution of depleted uranium as an environmental risk factor: lessons from other metals, Int. J. Environ. Res. Public Health, 3(2), 129-135 (2006).

[26] M. L. Albina, M. Belles, M. Gomez, D. J. Sanchez, J. L. Domingo, Influence of maternal stress on uranium - induced developmental toxicity in rats, Exp. Biol. Med. 228, 1072-1077 (2003).

[27] L. S. Morton, C. V. Evans, G. O. Estes, Natural Uranium and Thorium distributions in podzolized soils and native blueberry, J. Environ. Quality, 31, 155-162 (2002).

[28] D. J. Shaw, Electrophoresis, Academic Press, London pp. 99-103 (1969).

[29] B. B. Tewari, Determination of stability constants of iron(III) and chromium(III)-nitrilotriacetate-methylcysteine mixed complexes by electrophoretic technique, Bull. Chem. Soc. Ethiop 18 (1), 29-36 (2004).

[30] B. B. Tewari, Ionophoretic studies on mixed metal - nitrilotriacetate - penicillamine complexes, J. Chromatogr. A, 910, 181-185 (2001). 
[31] B. B. Tewari, Paper Ionophoretic technique in the study of mixed complexes, Bull. Korean Chem. Soc. 23(5), 705-707 (2002).

[32] J. R. Blackburn, M. M. Jones, Stereoselective in the metal complex catalyzed hydrolysis of amino acid esters - III, $J$. Inorg. Nucl. Chem. 35, 1605-1611 (1973).

[33] V. Jokl, Studies on complexation in solution with paper electrophoresis, J. Chromotogr. 6, 432-439 (1964).
[34] A. E. Martell, R. M. Smith, Critical Stability Constants, Vol. 1, Amino Acids, Plenum Press, New York, 1974, p. 7.

[35] D. D. Perrin, Stability constants of metal ion complexes, IUPAC Chemical Series NO. 22, Part B, Organic Ligands, Pergamon Press, Oxford, 1979, p. 324. 